\title{
TWO PHOTOGRAPHED AMERICAN COOT $x$ COMMON GALLINULE HYBRIDS
}

\author{
RICHARD A. ERICKSON, San Diego Natural History Museum, P. O. Box \\ 121390, San Diego, California 92112; richard.erickson@lsa.net \\ STEPHEN C. ROTTENBORN, H. T. Harvey \& Associates, 983 University Ave., \\ Bldg. D, Los Gatos, California 95032; srottenborn@harveyecology.com
}

ABSTRACT: To the three previous reports of hybrids of the American Coot $\times$ Common Gallinule we add two, one from Mountain View, California, in July 1995 and one from Tijuana, Baja California, in December 2019 and January 2020. The hybrids were similar in their coot-like build and intermediate plumage coloration, but they differed in size, bill and leg coloration, extent of lobes on the toes, and some plumage details. The one in Tijuana was larger than either parental species but made vocalizations of both species. Such intergeneric hybrids are rare, but at least $11 \mathrm{ex}-$ amples of Fulica $\times$ Gallinula have been reported from the Old World.

Fulica (coots) and Gallinula (moorhens and gallinules) are widespread related genera that share many habits and habitats. Intergeneric hybrids between the Eurasian Coot (F. atra) and Eurasian Moorhen (G. chloropus) are rare but have been well documented in Europe (McCarthy 2006). Hybrids between their American counterparts, the American Coot (F.americana) and Common Gallinule (G. galeata), have been reported three times previously (Louisiana, McIlhenny 1937; northern California and Colorado, Brinkley 2001:137). However, no specimen or photo exists, and this cross remains largely unknown; e.g., it is not mentioned in the Birds of North America accounts by Bannor and Kiviat (2002) or Brisbin and Mowbray (2002). Intergeneric hybrids are uncommon in birds, but many pairings have been recorded, particularly in waterbirds (Ottenburghs 2019). The deeper divergence between these lineages (10-15 million years ago in the case of Fulica and Gallinula; Garcia-R. et al. 2014) results in a higher chance of pre- or post-mating reproductive incompatibilities. Here, we report the details of two observations of American Coot $\times$ Common Gallinule hybrids, both photographed, one each from California and Baja California.

\section{CALIFORNIA RECORD}

On 22 July 1995, Michael J. Mammoser and Rottenborn found an adult American Coot $\times$ Common Gallinule hybrid in the Stevens Creek Nature Study Area adjacent to Shoreline Park in Mountain View, Santa Clara County, California. The bird was with American Coots, and although it was similar in overall size and shape to the coots, the unusual bill coloration caught the observers' attention, leading to closer scrutiny. Rottenborn returned on 24 July and was able to study the bird more closely before visiting nearby areas to look at Common Gallinules for comparison.

The bird's head, neck, and body were slightly smaller than on coots in direct comparison, but still larger, thicker, and bulkier (in proportion to body size) than on Common Gallinules studied subsequently (Figures 1 and 2). The head was large and blocky like that of a coot, not small and rounded as on a 
gallinule, and the neck was proportionately thicker than on a gallinule. The bill pattern differed from both parent species. The top of the frontal shield was rounded as on a coot, not squared off as on an adult gallinule. The frontal shield was bright red as on an adult gallinule, with this red extending forward along the culmen over the proximal one quarter to one third of the maxilla. Except for small, vague orangish patches near the base of the mandible and toward the distal end of the culmen, the bill was otherwise bright yellow like the tip of the bill of a gallinule rather than the ivory of a coot. The bill's shape was more coot-like, being slightly deeper, more gradually tapered toward the tip, and more blunt than that of a gallinule, but, in direct comparison, the bill was slightly more slender than on pure coots. The irides were bright red like those of adult American Coots, whereas irides of all seven adult Common Gallinules studied nearby on 24 July were a duller, deeper red, with most having a dull brownish tinge.

The back was slightly more brown than the slate-gray backs of the nearby coots, but lacking the extensive pure brown color of the back of a gallinule. All of the adult gallinules studied nearby on 24 July had plain brown feathers on the back and brown remiges, whereas those of the hybrid were a blend of brown and slate gray, contrasting less with the slate gray sides and neck than on the gallinules. Two white-striped gray feathers were present on each flank (such as would be found on a gallinule but not a coot), but most of the feathers of the sides and flanks were plain slate-gray as on a coot.

The structure of the toes looked perfectly intermediate between the two parent species (Figure 3). In direct comparison, the toes were proportionately longer and narrower than on a coot, with much smaller fleshy lobes along the edges. However, the narrow fringe of skin along the edges of the toes was more extensive than on a gallinule. The toes were greenish or yellowish-green, perhaps slightly more green than the legs; the toes of nearby gallinules were similarly colored, whereas the toes of coots seen in direct comparison were pale green with a bluish-gray cast, paler and less yellow than on the hybrid.

\section{BAJA CALIFORNIA RECORD}

On 9 December 2019, Erickson found an adult American Coot $\times$ Common Gallinule hybrid on Lago la Amistad in Parque de la Amistad, a city park on the east side of Tijuana, Baja California. The bird was superficially similar enough to the many coots present that he had actually walked past it before it made a gallinule-like call, and he turned back to look for the Common Gallinule that he then assumed to be present. Upon realizing its hybrid nature, Erickson spent some time watching and photographing this cooperative bird. René Valdés and Erickson returned to the park on 20 January 2020 and found the hybrid on the same portion of the lake as the previous month. Gerardo Marrón photographed the bird on 30 January 2020 (see this issue's inside back cover).

In all respects the hybrid acted like the coots with which it associated; all were well adjusted to human presence. On the water, the size and structure of the hybrid pretty well matched nearby coots, but the hybrid was slightly larger (heavier) than the coots (Figure 4). Positive heterosis is frequently observed in avian hybrids. Crosses between domestic chickens (Gallus gallus) and Hel- 


\section{AMERICAN COOT × COMMON GALLINULE HYBRIDS}

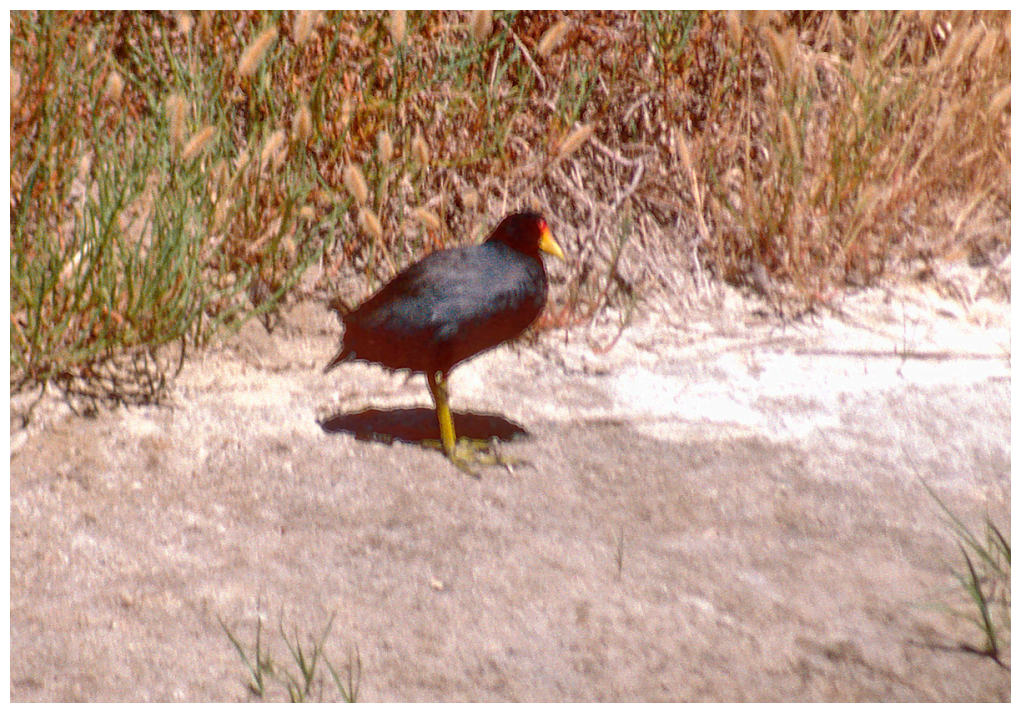

Figure 1. Overall coot-like shape, but unusual bright yellow and red bill, of hybrid American Coot $\times$ Common Gallinule in Mountain View, California, 24 July 1995.

Photo by Stephen C. Rottenborn

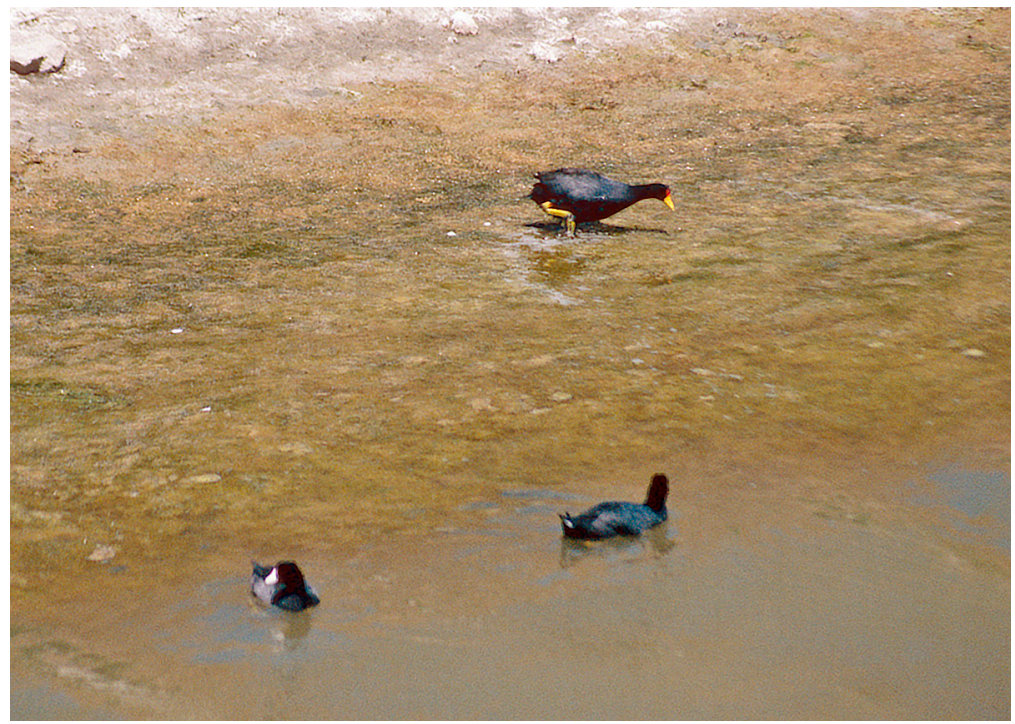

Figure 2. Comparison of size and shape between the hybrid American Coot $\times$ Common Gallinule and pure American Coots in Mountain View, California, 24 July 1995.

Photo by Stephen C. Rottenborn 


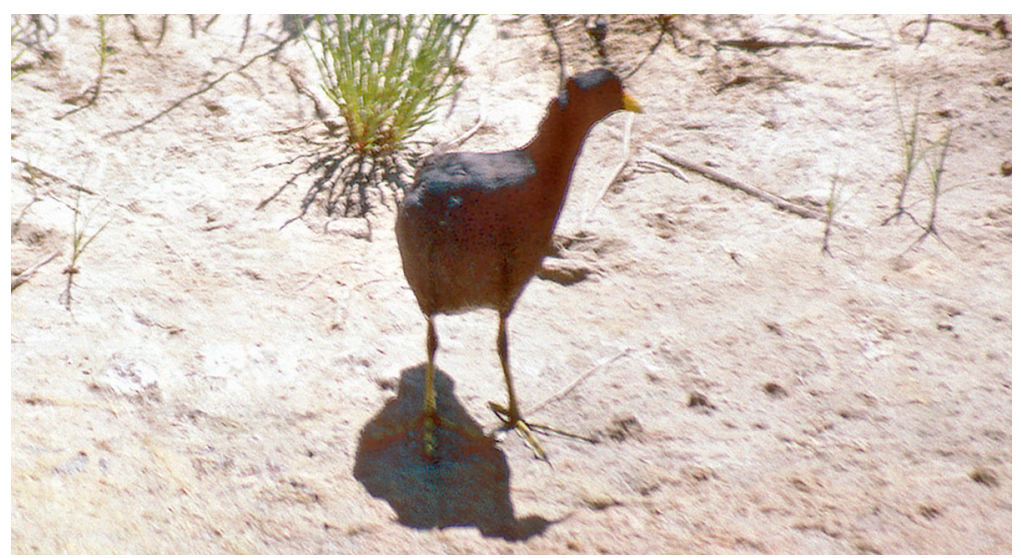

Figure 3. Toes of the hybrid American Coot $\times$ Common Gallinule in Mountain View, California, 24 July 1995; the fleshy lobes on the toes were more extensive than on a pure gallinule but smaller than on a coot.

Photo by Stephen C. Rottenborn

meted Guineafowl (Numida meleagris) may be up to twice as large as either parent (McCarthy 2006). The hybrid was observed during many interactions with coots and was dominant on every occasion. When the hybrid was on shore, the toes revealed themselves as lobed, much like a coot's (Figure 5).

In terms of bare-part coloration, the hybrid showed more intermediate characteristics. The bill and frontal shield were not white or black as on a coot but yellow and red as on a gallinule (Figure 6). The distribution of colors was

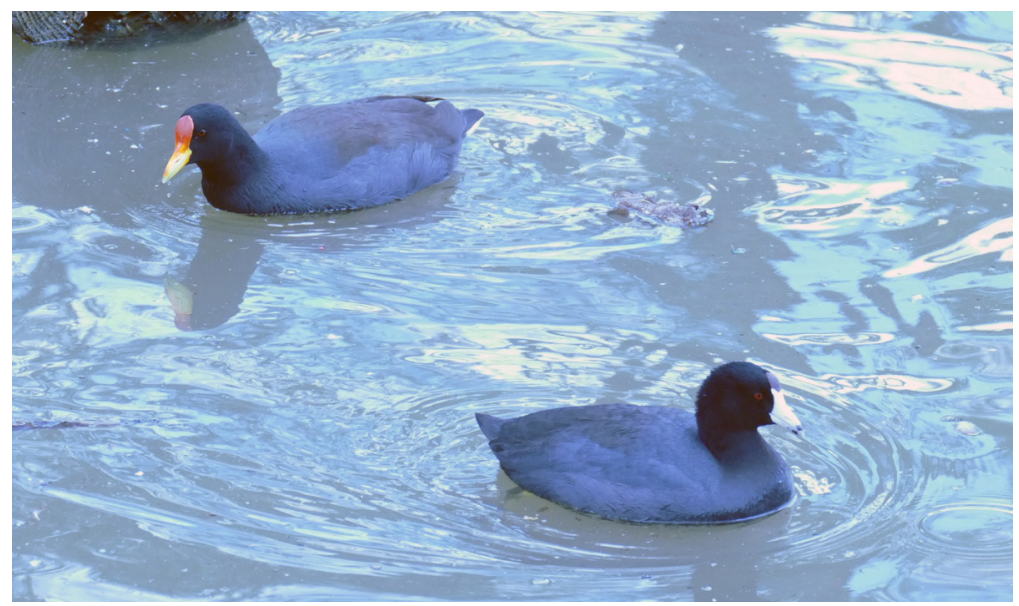

Figure 4. Size comparison of hybrid American Coot $\times$ Common Gallinule with American Coot in Tijuana, Baja California, 9 December 2019.

Photo by Richard A. Erickson 


\section{AMERICAN COOT × COMMON GALLINULE HYBRIDS}

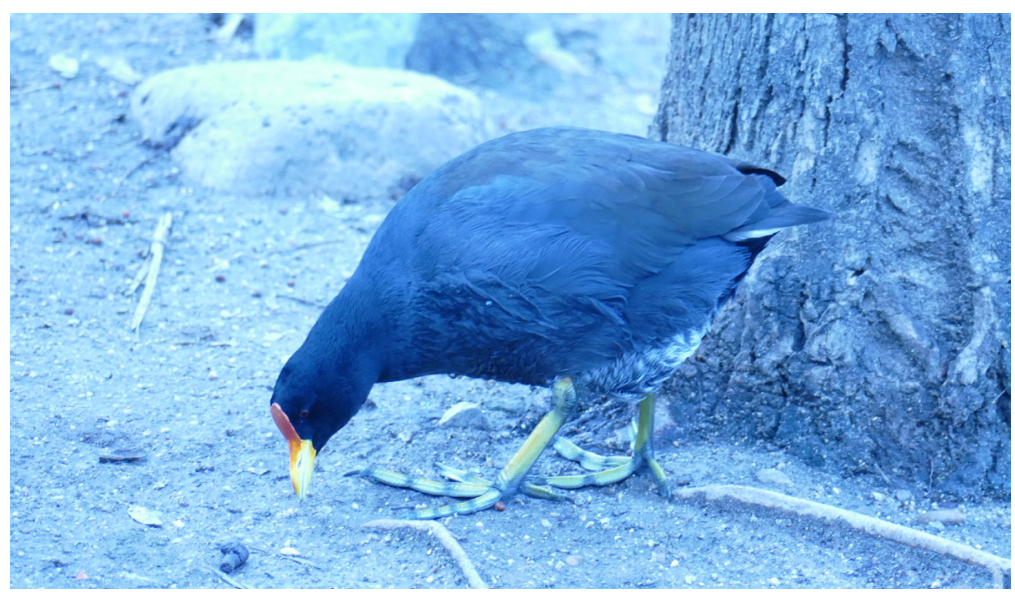

Figure 5. Hybrid American Coot $\times$ Common Gallinule in Tijuana, Baja California, 9 December 2019, showing overall structure and lobed toes similar to those of an American Coot.

Photo by Richard A. Erickson

different than on a gallinule, however, with the shield red and the bill primarily pale yellow, with traces of reddish at the base and tip of the maxilla and at the base of the mandible. Only a hint of reddish color was visible above the intertarsal joint (Figures 5 and 7), much reduced from what an adult gallinule shows.

The hybrid's plumage was also intermediate between the two species. There was no evidence of the white flank stripes that show on gallinules. The upperparts were largely brownish (Figure 7), unlike a coot's, but they

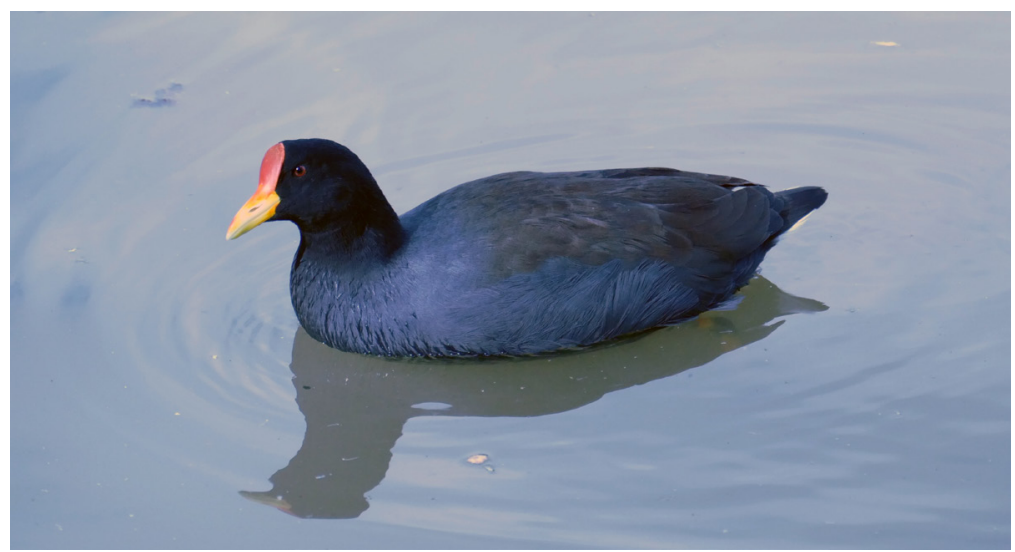

Figure 6. Quizzical hybrid American Coot $\times$ Common Gallinule in Tijuana, Baja California, 9 December 2019, showing details of bill and frontal shield coloration.

Photo by Richard A. Erickson 


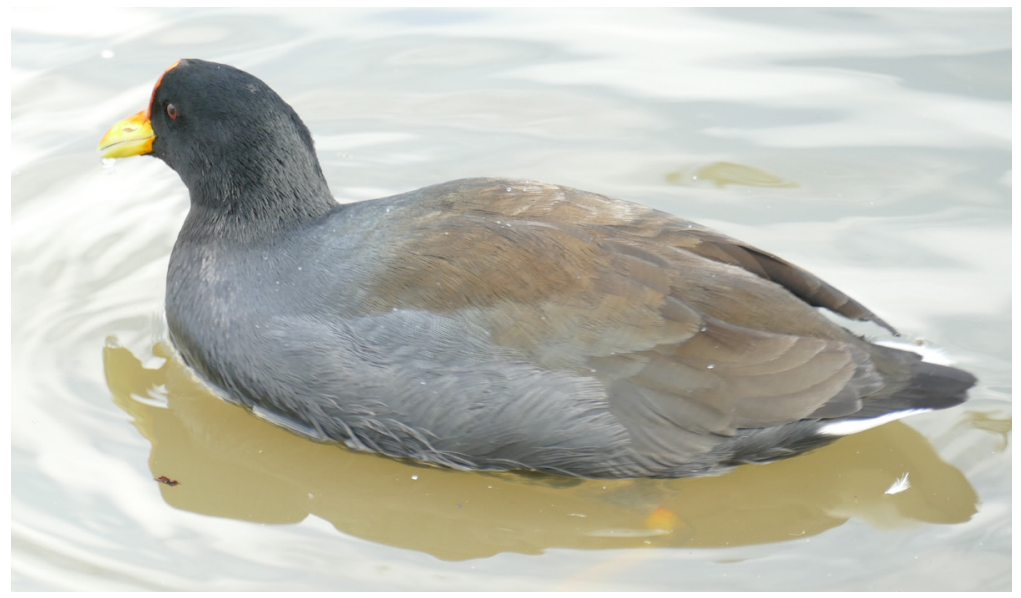

Figure 7. Hybrid American Coot $\times$ Common Gallinule in Tijuana, Baja California, 9 December 2019, showing close-up of the upperparts.

Photo by Richard A. Erickson

were much less richly colored than on a gallinule. There was more whitish mottling on the hybrid's belly than on any nearby coot, though the potential significance of this is unclear.

The hybrid called occasionally. Most notable was a "keek" call much like the typical gallinule "keek" described by Pieplow (2017). The bird also uttered several low volume "grunts," perhaps within the range of variation for the American Coot "croak" described by Pieplow (2017). Examples of both calls are included at www.ebird.org/checklist/S63668709.

\section{DISCUSSION}

We were unable to obtain any more information on the appearance of the previous California and Colorado hybrids, but McIlhenny (1937) described the Louisiana bird as follows: "red beak of the Florida Gallinule with the white shield above the beak as in the Coot. The eyes were colored as in the Florida Gallinule. The legs were like those of the Florida Gallinule even to the color and the red bare space above the knee joint [i.e., ankle]. The feet were semi-palmated like the Coot's and the entire body coloring and general body build were like that of the Coot, except the plumage of the back which had the coloring of the Florida Gallinule. The bird was much smaller than an adult Coot." So the Mountain View, Tijuana, and Louisiana birds were similar in overall coot-like build and overall plumage coloration, but they varied in size, bill and leg coloration, foot structure, and some plumage details, variability not unexpected in F1 hybrids. McCarthy (2006) described European hybrids as having "traits both of Common Coot (size and lack of white on flank) and of Common Moorhen (white undertail and green legs)." Numerous photographs were published by van Balen et al. (2001) and Rodríguez et al. 
(2010). Van Balen et al. (2001) were the only ones to discuss vocalizations of any of these hybrids, describing calls unlike either parent species.

Both American Coots and Common Gallinules breed in the Mountain View area, and that bird may have resulted from local breeding. The provenance of the Tijuana hybrid is unknown. Lago la Amistad is managed irregularly and typically provides habitat for a wide range of waterbirds (e.g., www. ebird.org/checklist/S62180263 and https://ebird.org/checklist/S63668709, which also include additional photographs of the hybrid). Marsh habitat is not extensive and varies in quality, but has been sufficient to support nesting coots, gallinules, and even White-faced Ibis (Plegadis chihi) on occasion (approximately 20 birds in 2008 and 2019, Erickson pers. obs.). Nevertheless, given the small sizes of the local populations, it seems more likely that the hybrid came from elsewhere and arrived on the lake with the large number of coots that descend upon the region in winter.

We thank Matthew J. Baumann, Edward S. Brinkley, Marshall J. Iliff, James M. Maley, Steven G. Mlodinow, Scott B. Terrill, Jeremiah Trimble, Philip Unitt, René Valdés and an anonymous reviewer for assistance in preparation of this note, including providing a few entire contextual sentences (with references) included here.

\section{LITERATURE CITED}

Bannor, B. K., and Kiviat, E. 2002. Common Gallinule (Gallinula galeata), in The Birds of North America (A. F. Poole and F. B. Gill, eds.), no. 685. Birds N. Am., Inc., Philadelphia; doi 10.2173/bna.685.

Brinkley, E. S. 2001. The changing seasons: Winter 2000-2001. N. Am. Birds 55:132-139.

Brisbin, I. L. Jr., and Mowbray, T. B. 2002. American Coot (Fulica americana), in The Birds of North America (A. F. Poole and F. B. Gill, eds), no. 697. Birds N. Am., Inc., Philadelphia; doi 10.2173/bna.697a.

Garcia-R., J. C., Gibb, G. C., and Trewick, S. A. 2014. Deep global evolutionary radiation in birds: Diversification and trait evolution in the cosmopolitan bird family Rallidae. Molec. Phylogen. Evol. 81:96-108; doi 10.1016/j.ympev.2014.09.008.

McCarthy, E. M. 2006. Handbook of Avian Hybrids of the World. Oxford Univ. Press, Oxford, England.

McIlhenny, E. A. 1937. Results of the 1936 bird banding operations at Avery Island, Louisiana, with special reference to sex ratios and hybrids. Bird Banding 8:117-121; doi 10.2307/4509457.

Ottenburghs, J. 2019. Multispecies hybridization in birds. Avian Research 10(20); doi 10.1186/s40657-019-0159-4.

Pieplow, N. 2017. Field Guide to Bird Sounds of Eastern North America. Houghton Mifflin Harcourt, New York.

Rodríguez, B., Curbelo, J., and Carrasco, N. 2010. Hybrid Eurasian Coot Fulica atra $\times$ Common Moorhen Gallinula chloropus on Tenerife, Canary Islands. Bull. Afr. Bird Club 17:207-209.

Van Balen, J. H., Perdeck, A. C., and van Diek, H. 2001. Hybridisatie tussen Waterhoen en Meerkoet [Hybridization between Common Moorhen and Eurasian Coot]. Dutch Birding 23:196-202. 